\title{
Rethinking the Option of Violence in Politics and the Fate of Tiberius Gracchus
}

\author{
Gill Oluwatosin Adekannbi \\ Department of Classics, University of Ibadan, Ibadan, Nigeria \\ E-Mail: tsn_ade@yahoo.com
}

\begin{abstract}
The killing of Tiberius Gracchus along with hundreds of his supporters in factional violence has left an imprint of moral controversy. When perpetuated by the aggrieved or oppressed masses, violence is seen as an act of aggression or rebellion. However, it tends to be termed political expediency when initiated by the ruling power or its agency. Using interpretive approach, this paper sets aside justifying the murdering of Tiberius as removal of a potential tyrant who was causing public disturbance. The research, after highlighting how violence became imminent when other legitimate efforts at resolving political conflicts failed, shifts to the moral question arising from resorting to violence as the ultimate tool for achieving a political goal. Corrupt members of the Roman Senate and their supporters would share the view: 'so perish also all others who do such things'. However, the paper notes the benefits of Tiberius' agrarian reforms to the poor citizens and the potential benefits of the changes to the state. The conclusion is: the champion of the people had acted well enough but inconclusively to reach his goals. It remained for him and his supporters to stand against being outmaneuvered by the corrupt politicians. If violence had been used by Tiberius and his followers against the senate to succeed, the common people would have declared this as both morally justifiable and politically expedient. Hence, it is theorised that, when moral questions are unanswered in politics, violence looms and no one may have the monopoly of it.
\end{abstract}

Keywords: Political Violence, Roman Republic, Tiberius Gracchus, Morality, Expediency

\section{INTRODUCTION}

The possibility of a blurry border line between criminality and political expediency could be a serious issue, especially when violence becomes the tool for achieving a political end. Violence in this paper represents application of physical force, which may vary in intensity against others, to achieve the desired result. Often occurring in form of a behaviour that may bring injury or death, violence could be understood as antonymous with the use of persuasion or reliance on the legal procedure to right wrong or perpetuate an established order. Political expediency, on the other hand, implies a political action that is performed simply because it is considered suitable for attaining a goal or purpose, typically without consideration for legality or morality. Viewed as different from beer parlour fray and other scuffles such as a street fight or a clash over a football match, the justification for political violence often emanates from labelling an opponent a criminal or an oppressor. The case of Tiberius Gracchus, a Roman tribune in the late 2nd century B.C.E., would always come to mind when examining what would controversially remain a legitimate use of violence. Considering the events of 133 B.C.E., moral issues tend to arise: who deserves to use violence as a weapon of political expediency; the oppressor or the oppressed? Put another way, when is the use of political violence morally justifiable? This paper re-examines the events leading to the assassination of Tiberius Gracchus. However, a discussion on the relationship between violence and political expediency requires giving some historical background to how violence got a place in the Roman politics by the time of Gracchus.

\section{A BACKGROUND TO VIOLENCE DURING THE REPUBLIC}

It may not be difficult to trace the root of the prevalent violence in the late Roman Republic since 'the annals of the early Roman Republic, as we find them in Livy and Dionysius of Halicarnassus, are filled with stories of violence associated with the struggle between patres and plebs' (Lintott, 1970, p.12). Although the case of violence involving Tiberius Gracchus often generates great interest, the Roman history's record of tradition of political violence predating this period is ever pertinent. Violence in Rome at the earlier period particularly began with the struggle between the Plebeians (commoners) and Patricians (aristocrats) in 494 B.C.E. and lasted till 287 B.C.E (Brenda \& James, 2006, p. 492). The Conflict of the Orders positioned the Plebeians against the Patricians in the former's keen contest for political equality with the latter.

The Plebeians played a crucial role in the Roman society as farmers, craftsmen, and labourers. But their major place in the Roman army would give the Patricians a more compelling reason to admit that they needed the Plebeians more than the Plebeians needed them. In some 400 years, the city state of Rome would expand militarily, not only to become the dominant power on the peninsula of Italy, but also to gain mastery over the entire Mediterranean world. Yet, the nobility was most unwilling to share all political privileges or authorities with the Plebeians, some of whom had become rich and influential. The suppression or dominance was to the point that 'the senate tried to drown the voice of the tribunes in the uproar of so many wars by ordering a levy to be made and all preparations for war pushed on with the utmost vigour' (Livy, 4.1). The 
Patricians apparently maintained a united front against the Plebeians in a socio-political state of crisis engendered by 'the control of the Republic by a few families and the exclusion of a large segment of the population from political participation' (Raaflaub, 1986, p. 301). Since the Roman nobility would persistently strive to sustain both its economic and political status in the society where others eagerly wanted some share of these, it should be convenient to understand the unfolding political progression as follows: 'the violence of the young nobles in defence of the established order ... part of the basic tradition of early Republican history and firmly established by the time of Cicero's education. Little was known about [the young nobles] apart from their use of violence' (Lintott, 1970, p.29). Brewing trouble, the monopoly of state offices by the wealthy Patricians was clearly observed as a dimension of social injustice. An instance of this is expressed below:

'Who doubts that in a City built for all time and without any limits to its growth new authorities have to be established, new priesthoods, modifications in the rights and privileges of the houses as well as of individual citizens? Was not this very prohibition of intermarriage between Patricians and Plebeians, which inflicts such serious injury on the commonwealth and such a gross injustice on the plebs, made by the decemvirs within these last few years? Can there be a greater or more signal disgrace than for a part of the community to be held unworthy of intermarriage, as though contaminated?' (Livy 4.2)

Livy here describes a moral problem: 'prohibition of intermarriage between Patricians and Plebeians'. Supposedly to prevent blood contamination, the ten-men commission (decemvirs) of the noble class viewed the Plebeians as socially inferior, unfit to have access to the political rights which attaining the Patrician rank through marriage would make possible. The despicable view of the Plebeians is similarly explicit in the thought of the aristocratic class as exemplified by the following: 'What other result would mixed marriages have except to make unions between patricians and plebeians almost like the promiscuous association of animals?'(Livy 4.2).

Subsequent events in Roman history indicate that such 'exclusion of a large segment of the population from political participation' (Raaflaub, 1986, p301.) was a tense socio-political situation that predisposed both the nobles and the general populace to the tool of violence. Although the Patricians would maintain their tight grip of power, they well knew 'popular rage... [could] habituate the people to inflict punishment on the Patricians' (Livy 3.52). Indeed, while the Roman Republic could only make progress through making of concessions, 'it would appear that the violence in the period influenced the nature of the compromises that were eventually achieved between the two groups' (Brenda \& James, 2006, p.494). Legal concessions remained inadequate in resolving the impasse and the uneasy atmosphere that prompted resorting to violence is further portrayed thus:
'The consuls began to rouse the senate to take action against the tribunes, and at the same time the tribunes were getting up an agitation against the consuls. The consuls declared that the revolutionary proceedings of the tribunes could no longer be tolerated, matters had come to a crisis, there was a more bitter war going on at home than abroad. This was not the fault of the plebs so much as of the senate, nor of the tribunes more than of the consuls. Those things in a State which attain the highest development are those which are encouraged by rewards; it is thus that men become good citizens in times of peace, good soldiers in times of war. In Rome the greatest rewards are won by seditious agitations, these have always brought honour to men both individually and in the mass...There was no final settlement in sight, nor would there be as long as agitators were honoured in proportion to the success of their agitation.' (Livy 4.2)

Since the consuls belonged to the Patrician class that always sought to protect its interest, the incline was often doing things that would undermine the growing influence of the Plebeians. Hence, 'the consuls began to rouse the senate to take action against the tribunes', employing the state machinery to silence the opposition. The nobility became so much intolerant and anxious about 'revolutionary proceedings of the tribunes' and this culminated in 'a crisis' that is described as 'a more bitter war going on at home than abroad'. Livy notes something was morally amiss when he says 'in Rome the greatest rewards are won by seditious agitations'. 'Seditious agitations' evokes the thought of violent strife which would be expressed through matching conducts or speeches that incite victims to rebellion. While revolts are usually deemed unlawful when they are directed against the constituted authorities, Livy interestingly remarks that the violent actions employed in this circumstance had 'always brought honour to men both individually and in the mass' in the Roman Republic. However, in being armed with the law, the Tribunes of the people never saw themselves as inferior to consuls of the aristocratic class.

As the peak of the foregoing situation may seem a justification for a politician in "authority" to turn to violence as the ultimate weapon to stabilise the state, it also generates the issue of when use of violence for political ends becomes legitimate or morally acceptable. As far as Livy is concerned, 'there was no final settlement in sight, nor would there be as long as agitators were honoured in proportion to the success of their agitation' or there might be no fair arbiter who is devoid of force. Although Rome's development from a city-state into a world empire was more real by the Late Republic, the state's growing military might offered no peaceful resolution to the emerging socioeconomic problems. The influx of wealth experienced by Rome after the defeat of Carthage, rather than ushering in a period of socio-economic prosperity and political stability, heralded a period of turbulence. In fact, the political ambiance exacerbated to the point that violence almost became inseparable companion of politics. Hence, the conclusion again is reached: '[t]o speak of Roman politics 
in the late Republic without touching on violence would hardly be possible' (Sherwin-White, 1956, p.1). Violence, even when it was undesirable, had become apolitical option.

\section{POWER AND WEALTH IN THE THROES OF POLITICAL VIOLENCE}

An explanation for increase of violence in domestic politics amidst Roman economic plenty may not be far-fetched. The expansion of the Roman state offered better avenues for more wealth to both the Patricians and the rich Plebeians to explore abroad. As noted above, the Conflict of the Orders witnessed some political violence but a greater stage was set for violence by the Late Republic when politics became a more serious business with more financial benefits to boost individual prestige and status. (Yakobson, 1992, p.180).This would in time lead to a full blown affinity for blood, brutality, and power; when the Roman politicians' competition for political offices became keener and reckless in the spirit of the gladiatorial games. A precursor or rather a viable accomplice to political violence was electoral bribery. Roman office seekers generally saw no evil in bribing the electorate to win elections, indeed, 'in Roman politics it is hard to refute the suggestion that the sort of people who actually held magistracies was not seriously influenced by electoral bribery' (Lintott, 1990, p.1). Although there were Roman legislations against electoral bribery (Lintott, 1990), its use was as deeply entrenched as violence by the late Republic. It could be reasoned that when and if bribery failed, violence would accomplish the job. The link between the two perhaps is more obvious when the etymology for the Latin word for bribery is considered. The word, bribery, rendered ambitus, is 'connected with the verb ambire, 'to go round', 'to canvass support', and with the noun ambitio, it expresses the concept of the pursuit of office and political fame (perhaps to excess)' (Lintott, 1990, p.1).Therefore, in the Roman politics, the relationship between bribery and violence may conjure the thought of jettisoning all moral considerations by illicit use of pecuniary means to achieve political goals. Polybius expressions are fitting words to theorise the selfseeking environment that would lead to an ugly turn of political violence:

'By which means when, in their senseless mania for reputation, they have made the populace ready and greedy to receive bribes, the virtue of democracy is destroyed, and it is transformed into a government of violence and the strong hand. For the mob, habituated to feed at the expense of others, and to have its hopes of a livelihood in the property of its neighbours, as soon as it has got a leader sufficiently ambitious and daring, being excluded by poverty from the sweets of civil honours, produces a reign of mere violence.' (Polybius, 6.9)

Although the two classes of the Patricians and the Plebeians continued to have their identities in the $2^{\text {nd }}$ and $3^{\text {rd }}$ century B.C.E., there was already a settlement that resulted in some relative peace: the rich 'Plebeians were absorbed into the higher nobility and became part of the new, expanded governing aristocracy, although the poorer Romans actually gained very little’ (Brenda \& James, 2006, p.496).Through various legislations, the Plebeians had made gains in the course of fighting unjust economic and social limitations imposed on them by the Patrician elite. Yet, the Roman nobility could hardly disguise the discontent with the settlements. Therefore, the reasoning was: 'Tribunes of the plebs and the senate could not exist in the same State, either that office or this order (i.e. the nobility) must go. Their insolence and recklessness must be opposed and better late than never' (Livy 4.2). Political violence was set to take to take another direction and its flame must soon flare up.

\section{THE RISE OF TIBERIUS GRACCHUS AND THE IMMINENCE OF TRAGIC VIOLENCE}

The two ideological political groups that emerged by the late Republic, Optimates and Populares, provided the background to the renewed violent political struggles that eventually ended the Republic. The new power of the Plebeians would become a course for factional struggle within the nobility which kept striving to hold on tenaciously to power and profit from holding the key offices. The Populares, would take advantage of their knowledge of the call for extension of voting rights, relief from poverty and meeting the agrarian needs, to rise as champions of greater role for the common people. In reaching their political goals, the Populares, often clad with the power of assemblies of the people to facilitate smooth passage of their laws, set themselves on a collision course with the Optimates whose senatorial influence they defied. The two groups with conflicting outlooks both aimed at occupying the state offices. The conservative Optimates, sticking to the old oligarchic ideals, stood against the change and radical measures advocated by the Populares who were regarded as demagogues, prone to tyranny. The source of support and the pattern of the violence that ensued are described below:

'The leaders of the Populares were more likely to seek the support of the crowd in Rome at least some of the time, but the Optimates never ignored the political potential of the people... The violence took two basic forms that eventually became inter-related. The first form involved the willingness of political leaders to use their own armed retainers or to mobilize Roman crowds or mobs to intimidate their political opponents. The second form of violence was the political murder of opponents, which began in 133 BCE and culminated in the assassination of Julius Caesar’ (Brenda \& James, 2006, pp. 497-498).

The source of the recruits for political violence is identified as the 'Roman crowds'. While the Populares relied more on the crowd for support, politicians of the Optimates' group would also 'mobilize Roman crowds or mobs to intimidate their political opponents'. This political atmosphere that was the aftermath of the long period of the struggle with Carthage made the recourse to violence progressively 
unavoidable. A small class of senators who belonged to the Optimates would like to stream to only themselves the flood of torrential booty that enlivened the Roman economy. It is on record that 'the rich began to offer larger rents and drove out the poor' (Plutarch, TG,8.1). However, Tiberius Gracchus, although of a noble background, advanced his political career as a member of the Populares, catching on support from the downtrodden who desperately needed a champion. Tiberius Gracchus identified the problem as follows:

'The wild beasts that roam over Italy," he would say, "have every one of them a cave or lair to lurk in; but the men who fight and die for Italy enjoy the common air and light, indeed, but nothing else; houseless and homeless they wander about with their wives and children. And it is with lying lips that their imperators exhort the soldiers in their battles to defend sepulchres and shrines from the enemy; for not a man of them has an hereditary altar, not one of all these many Romans an ancestral tomb, but they fight and die to support others in wealth and luxury, and though they are styled masters of the world, they have not a single clod of earth that is their own' (Plutarch, TG, 9.4-5).

Tiberius Gracchus hints on a moral problem when he accused the Roman leaders of the Optimates class of 'lying lips'. Yet another morally unjust situation is explicit when individuals 'fight and die to support others in wealth and luxury' and then live in penury. Yet, the conservative aristocrats in the senate would do everything to resist Tiberius' passage of law that would alleviate the suffering of the common people. A climate of the violence that was soon to erupt is expressed next:

'While these classes were lamenting and indulging in mutual accusations, a great number of others composed of colonists, or inhabitants of the free towns, or persons otherwise interested in the lands and who were under like apprehensions, flocked in and took sides with their respective factions. Emboldened by numbers and exasperated against each other they attached themselves to turbulent crowds, and waited for the voting on the new law, some trying to prevent its enactment by all means, and others supporting it in every possible way’ (Appian, 1.7).

Self-interests urged all the parties on and made them desperate and increasingly disposed towards violence: 'the men of property... in secret ...plotted against the life of Tiberius and tried to raise a band of assassins to take him off...Tiberius on his part ... wore a concealed short-sword such as brigands use' (Plutarch, TG,10.7). Reliance on 'turbulent crowds' was not unusual and Tiberius Gracchus counted very much on the majority's support, as much as he did on the use of the law. However, the propensity of the rich toward violence became more real 'when the appointed day [came] and Tiberius was summoning the people to the vote, the voting urns were stolen away by the party of the richand great confusion arose' (Plutarch, TG, 11.1). 'The rich' would employ all means to frustrate a democratic process by sponsoring the stealing of the 'voting urns'. At this time, Tiberius Gracchus supporters seemed not ill prepared for occurrence of violence so that they considered themselves 'numerous enough to force the issue, and were banding together for this purpose'(Plutarch, TG, 11.1). Nevertheless, since violence was viewed inappropriate, it was averted when two respected men who were present prevailed on Tiberius to refer the matter to the senate (Plutarch, TG, 11.1). Until the moment, Tiberius Gracchus had trusted in the weapon of the law to achieve his objectives and he assented to allowing the constituted authority to intervene.

To Gracchus' disappointment, 'the senate in its session accomplished nothing, owing to the prevailing influence of the wealthy class in it'(Plutarch, TG,11.2). The stubborn refusal of the rich in the senate to act as impartial arbiters further made the political atmosphere more tense as 'Tiberius resorted to a measure which was illegal and unseemly' (Plutarch, TG,11.2)to achieve the passing of the land reform bill. The physical resistance that originated from the senate was complemented with the bribing of another Tribune to veto the bill of Gracchus. With the situation becoming more desperate for Gracchus, an unprecedented use of law was viewed the only way forward when all efforts to deter Octavius' opposition to his bill failed.

It is on record that 'Tiberius called a halt in the voting, and again entreated Octavius, embracing and kissing him in the sight of the people, and fervently begging him not to allow himself to be dishonoured'(Plutarch, TG,12.3). At this time the popular assembly was so much convinced that it had a champion in Tiberius Gracchus and was all poised to use its voting power to remove every obstacle in the way. Octavius, the embattled Tribune, seemed well aware of what was imminent, and he 'was not altogether untouched or unmoved; his eyes filled with tears and he stood silent for a long time. But when he turned his gaze towards the men of wealth and substance who were standing in a body together' (Plutarch, TG, 12.3), he gave way to fear and would not yield to the will of the people.

The Tribune had more consideration for his reputation among the powerful rich than for solving the economic crisis in the countryside, restoring the displaced farmers to their lands and place in the state. Although his removal from the office was done through an electoral process, the people had become so bitter against Octavius who was practically violently removed from the venue. The sight of the tumultuous affair is described thus: 'the people made a rush at him, and though the men of wealth ran in a body to his assistance and spread out their hands against the crowd, it was with difficulty that Octavius was snatched away and safely rescued from the crowd'(Plutarch,TG,12.3).

Then, the agrarian bill was passed and, with the suppression of the opposition, Gracchus moved on to secure election of another tribune to replace Octavius. However, incidents of 
violent acts had left their portentous imprints. The unfolding events signaled the point of violence that was reached in the history of Roman politics during the late Republic: when bribery failed, violence tended to be the viable option. Tiberius Gracchus would swim in the political water that was getting hotter when members of the aristocratic opposition 'who were vexed ... and feared the growing power of Tiberius, heaped insult upon him in the senate. Tiberius' request for 'the customary tent at public expense for his use when dividing up the public land' (Plutarch, TG,13.2) was denied. The resistance of Scipio Nasica, the pontifexmaximus, against Tiberius Gracchus was especially bitter and vigorous because the agrarian bill would cause him a great loss as 'he was a very large holder of public land' (Plutarch, TG, 13.3). Nasica's stance was representative of the senatorial opposition and the chief priest only needed a little more time to spearhead a deadly attack against Gracchus’ movement.

The rich who dominated the senate, in addition to loss of the land they were in illegal possession of, saw the control of Rome slipping from the hand of the senate to that of the popular assembly. In the unfolding development, Tiberius Gracchus was desperate for a re-election and the support of his followers never diminished as it is next expressed:

'The poor were moved with deep sorrow, and rightly so, both on their own account (for they believed that they were no longer to live in a free state under equal laws, but were reduced to servitude by the rich), and on account of Gracchus himself, who had incurred such danger and suffering in their behalf. So they all accompanied him with tears to his house in the evening, and bade him be of good courage for the morrow. Gracchus cheered up, assembled his partisans before daybreak, and communicated to them a signal to be displayed in case of a fight' (Appian, 1, 2.15)

Violence seemed the last option for the conflict resolution. The senatorial faction saw no alternative to this and the time had come for Nasicato act, as if under religious or moral obligation, to save himself and his colleagues from loss of power and property: Below is the call to violence:

'Cornelius Scipio Nasica, the pontifex maximus, leading the way and calling out with a loud voice, "Let those who would save the country follow me." He wound the border of his toga about his head either to induce a greater number to go with him by the singularity of his appearance, or to make for himself, as it were, a helmet as a sign of battle for those who looked on, or in order to conceal from the gods what he was about to do. When he arrived at the temple and advanced against the partisans of Gracchus they yielded to the reputation of a foremost citizen, for they saw the Senate following with him' (Appian, 1, 2.16)

Although Tiberius Gracchus had mobilised public support from among the lower classes who endorsed his measures and backed the legislations that were aimed at actualising his reforms, the chief high priest felt compelled to avert the threat Tiberius meant to the position of the nobility. The issue was not whether the reforms would meet the needs of the majority who were in dire economic straits, it was rather that 'the nobles opposing him ...some of the key elements of the existing political system were under attack' (Brenda \& James, 2006, p.500). All constitutional and political manoeuvres employed to frustrate Tiberius Gracchus seemed to have failed and violence with some semblances of piety act became the ultimate weapon. When Cornelius Scipio Nasica raised 'a loud voice', his audience must have sensed a strong call to a revolutionary action that suggested use of violence.

In seeming triumph by the authority of his office, he roused in his supporters some patriotic feelings when he said 'Let those who would save the country follow me'. The summon to aggression was intensified as 'He wound the border of his toga about his head either to induce a greater number to go with him... or to make for himself, as it were, a helmet as a sign of battle for those who looked on'. The thought of Nasica allegedly seeking to 'conceal from the gods what he was about to do' may evoke a thought of jettisoning of all moral considerations in politics. There was no doubt that Tiberius Gracchus' followers who were despairing about their champion were armed with weapons of violence to make their candidate succeed. Yet, in what may appear reverential, 'they yielded to the reputation of a foremost citizen [Scipio Nasica] for they saw the Senate following with him'. That became a tragic flaw as expressed by what followed:

'The latter wrested clubs out of the hands of the Gracchans themselves, or with fragments of benches or other apparatus that had been brought for the use of the assembly, began beating them, and pursued them, and drove them over the precipice. In the tumult many of the Gracchans perished, and Gracchus himself was caught near the temple, and was slain at the door close by the statues of the kings. All the bodies were thrown by night into the Tiber' (Appian, 1, 2.16)

While it has been argued that '[m]any of the attackers used improvised weapons to kill Tiberius, suggesting that the assault was not premeditated' (Brenda \& James, 2006, p.494), the atmosphere of tension and violence that preceded the event does not lend support to the excuse for the brutal killing of Tiberius and his supporters. For the rich land owners and other aristocrats in the senate, it was the much anticipated good riddance to a rising tyrant who almost subverted their influence. This shocking affair, the first that was perpetrated in the public assembly, was seldom without parallels thereafter from time to time' (Appian, 1, 2.17). Beyond the mixed feelings that the dreadful end of Gracchus understandably produced, the handling of the political conflict had set a historical precedent leading to the conclusion 'that the commonwealth no longer existed, but had been supplanted by force and violence’ (Appian, 1, 2.17). 


\section{WHEN USE OF VIOLENCE BECOMES POLITICALLY EXPEDIENT}

It is pertinent now to revisit the questions at the outset of this paper in the context of the fate Tiberius Gracchus: "who deserves to use violence as a weapon of political expediency; the oppressor or the oppressed?" "When is the use of political violence morally justifiable?" The answers to these questions might not be so simple. It can be argued that the use of violence to resolve conflict when Tiberius Gracchus sought another reelection was not unavoidable. The handling of matters by the contending factions, as reasoned below, could have been different as Plutarch's account next shows:

'This is said to have been the first sedition at Rome, since the abolition of royal power, to end in bloodshed and the death of citizens; the rest though neither trifling nor raised for trifling objects, were settled by mutual concessions, the nobles yielding from fear of the multitude, and the people out of respect for the senate. And it was thought that even on this occasion Tiberius would have given way without difficulty had persuasion been brought to bear upon him, and would have yielded still more easily if his assailants had not resorted to wounds and bloodshed; for his adherents numbered not more than three thousand. But the combination against him would seem to have arisen from the hatred and anger of the rich rather than from the pretexts which they alleged; and there is strong proof of this in their lawless and savage treatment of his dead body. For they would not listen to his brother's request that he might take up the body and bury it by night, but threw it into the river along with the other dead' (Plutarch, TG, 20.1-2).

Gracchus probably 'would have yielded still more easily if his assailants had not resorted to wounds and bloodshed'. Tiberius Gracchus had been labelled as overly ambitious and identified with a crowd that was disposed to violence and the powerful members of the senate who illegally occupied public lands would brutally get rid of him out of 'hatred and anger'. Nasica saw a situation that made it politically expedient to use violence to 'save the country'. Yet, rather than seeing the chief high priest as using his position to avert a danger to the state, it is easier to see violence used to suppress the will of the common people by the patricians who dominated the college of priests and the position of pontifexmaximus. The patricians viewed themselves as custodians of mosmaiorum, (ancestral traditions), the moral codes which the nobles considered Tiberius and his followers as violating. If anything was expedient, it should be supporting the course geared towards righting thewrong. While Tiberius Gracchus may be accused of demagoguery, he had clearly done a lot to endear himself to the masses in his pursuit of land reforms. He considered it politically expedient to doggedly but legally fight the senate control of public finances that stood in the way of the execution of the agrarian bill. Granted, he unprecedentedly sought election to a second tribunate in 132 purportedly to get the agrarian bill firmly established. If he had succeeded, he would have been celebrated as the saviour of the poor and his deeds possibly would have been no more politically faulted than Sulla's reforms and Julius Caesar's crossing the Rubicon to become a dictator. The agrarian reforms could have saved the lower classes; the landless farmers who had flooded from the countryside into Rome, from their misery earlier than it was the case. Significantly, the Roman urban poor residents could have regained their status and worth. The foregoing possibilities are now mere conjectures.

\section{CONCLUSION}

In understanding the point when use of violence appeared politically pragmatic, it should be noted that various weapons had been used to no avail by each of the two contending sides. Both parties had taken to legal provisions to checkmate each other. The corrupt and manipulative elite of the senate had reportedly bribed Octavius, while Tiberius repeatedly employed persuasion to dissuade his fellow tribune from supporting the rich against the poor. Now, it seemed all reconciliatory efforts had come to naught and the only imminent way out of the political logjam was violence. The two factions had access to violence and apparently equally needed it to expedite decisive action to protect their interests. All moral considerations might favourTiberius' followers being the first to be brutal. Besides being in the majority, they had been victims of socio-political inequality and the Roman legal structure was not strong enough to promptly salvage them. Yet, the senate faction seemed to know better when violence should not wait for the law and were not timid in extrajudicial use of it. If the Gracchan faction had acted faster against the oppressors, perhaps, history would have defined political expediency as when the oppressed take a timely political action to bring about moral justice. As the event of several decades later in Rome would show, seeing use of violence in politics as expedient at some points had got some ugly precedent. This moral issue haunting politics would be a good reference to the subjective meaning of political expediency. It has shown the tendency politics would for long have towards getting dirty in the absence of morality of right and constant presence of might is right. It could be reasoned that Tiberius missed the option of employing violence when it was politically expedient to do so. This is a political dilemma that remains unresolved. When violence looms, no one seems to have the monopoly of it. The moral aspect of this issue can be interrogated in another research.

\section{REFERENCES}

[1] Appian. (1899). The Civil Wars. Horace White, Ed.London: Macmillan and Co., Ltd.

[2] Brenda, J. L. \& James M. L. (2006). Political Violence in the Republic of Rome: Nothing New under the Sun. Government and Opposition, 41(4), 491-511. 
[3] Raaflaub, K. A. (1986). Social Struggles in Archaic Rome: New Perspectives on the Conflict of Orders, ed. Berkeley: University of California Press.

[4] Lintott, A. W. (1970). The Tradition of Violence in the Annals of the Early Roman Republic Historia: ZeitschriftfürAlte Geschichte, Bd. 19, H. 1, 12-29.

[5] Lintott, A. W. (1990). Electoral Bribery in the Roman Republic. The Journal of Roman Studies, 80, 1-16

[6] Livy, T. (1990). The History of Rome, Book 4. Canon Roberts, Ed. Retrieved fromhttp://www.perseus.tufts.edu/hopper/text.

[7] Livy, T. (1905). The History of Rome, Vol. 1. Canon Roberts trans. Retrieved from http://mcadams.posc.mu.edu/txt/ah/Livy/.

[8] Livy, T. (1919). The History of Rome, Book 1 Benjamin Oliver Foster, Ed.Cambridge. Cambridge: Harvard University Press.
[9] Sherwin-White, A. (1956). Violence in Roman Politics. Journal of Roman Studies, 46(1-2), 1-9. Retrieved from https://doi.org/10. 2307/jcd.297959.

[10] Yakobson, A. (1992). 'Petitioet Largitio: Popular Participation in the Centuriate Assembly of the Later Republic', Journal of Roman Studies, 82, 32-52. Retrieved from https://doi.org 10.2307/jcd.301283

[11] Polybius. (1889). Histories. Evelyn S. Shuckburgh, trans. London: Macmillan.

[12] Plutarch, L. M. (1921). The Parallel Lives The Life of Tiberius Gracchus. Retrieved from http://penelope.uchicago.edu/Thayer/e/ roman/texts/plutarch/lives/tiberius_gracchus. 